\title{
THE ROLE OF GOVERNMENT IN REGION DIFFERENCE OF FINANCIAL DEVELOPMENT AND ECONOMIC GROWTH: EMPIRICAL STUDY ON CHINA EVIDENCE
}

\author{
Pan Linwei ${ }^{1, a}$, Wu Yaling $\star^{2, b}$ \\ ${ }^{1}$ School of Economic and Management, Chongqing Jiaotong University, Chongqing, China; \\ ${ }^{2}$ School of Accounting, Chongqing University of Technology and Business, Chongqing, China \\ apanlinwei2000@sina.com, buyaling2005@sina.com
}

Keywords: regional financial difference, government participation, economic growth

\begin{abstract}
Based on the panel data of China during the period of 2000 to 2013, this paper empirically tests the effects of regional financial difference on economic growth, especially on the consideration of government participation. Our empirical evidence suggests that efficiency of financial system has a negative and significant effect on economic growth in 8 regions, but finance amount had different effect. And the amazing progress in GDP resulted mainly from fixed assets investment. Empirical results reports the effect of government participation has diverse effect on finance scale or finance transition efficiency in different regions. Government need choose appropriate approach to promote finance development according to different circumstance and conditions.
\end{abstract}

\section{Introduction}

China has experienced a remarkable economic growth in past 3 decades since the policy of open and reform in 1970's. We have to admit that government-oriented finance development played a crucial role in this progress. But we have no enough idea about the government role in the relation of financial development and economic growth. We attempt to answer these questions empirically and try to shed some light on the roles of government as well as other conditional variables in determination of financial development, which promote the rapid economic growth.

There are a number of theoretical and empirical studies have explored the relationship between the deepening of finance and economic progress at both national and provincial levels. Scholars are very interested in the massive forces of economic growth. Goldsmith (1969), Shaw (1973) and McKinnon (1973) have pioneering contribution and guidance to later literature. Based on panel data, empirical researches of Levine and Zervos (1998), Beck and Levine (2004) found that the stock market and banking development played significant roles in promoting the economic growth in long run. And there are also other researchers have devote their papers (e.g., Borensztein \& Ostry, 1996; Chen \& Feng, 2000; Chow, 1993; Chow \& Li, 2002; Wu, 2000; Yu, 1998). However, most of them have ignored a key driving force-the role of government at central and regional-especial in China.

We have noticed that government is always a leading role in the transition of centrally planned economy to market system. And government-oriented market economy has made more progress in China than expected in fact, the local governments play an even crucial and important role in the course of allocation of finance resources. There are three representative views about government's role in finance development and economic growth of China. Firstly, HE Dexu(2006) and ZHOU Ye'an(2007) noted that there is too much interference from central and local governments, and which go against finance deepening in China. On the contrary, CHEN Chao(2002), BAI Qinxian and JIAN Mei(2005) hold the argument that government has played an important role in rapid progress of China, especially in the field of policy-oriented finance and informal finance. With the deepening of research on the role of government, a new arguement has arisen that government need to secede as the construction of modern finance system has been finished. CHEN Yulu and MA Yong (2008) hold this view with SHI Enyi(2009,2011). Attempts to resolve this dilemma have resulted in the role of government in finance and economic, especially in the transition economy as China. 
Meanwhile, the previous studies do not provide much attention to the content of finance development. The development of finance is consist of expansion of finance scale, optimization of finance structure and improvement of finance efficiency, but not the scale. The three parts affect economic growth simultaneously in a country or region. But the result is different in different country or region, even different period in a country.

Ever since there are many pioneering contributions of previous works on the topic, and provide useful insights on some of the consequences of financial development or of financial reform, they do not address directly and comprehensively the question of whether financial liberalization has resulted in a more efficient allocation of finance resource in the process of rapid economic development in China. According to the report of Development Research Centre of the State Council of China, the traditional partition for region is no longer reflect real situation. This paper divided 31 provinces into 8 economic regions as 11th Five-Year development plan of China.

Under the base of 8 economic regions of China, this paper aims to examine the relationship between financial development and the role of government for the case of China over the period 2000-2013. Specifically, what kind of role has government played to the finance development and economic growth process? What kind of effect, positive or negative, has government exerted on finance development?

The rest of the paper is organized as follows. And Section 1 describes key variables and data resources, indicator measure and descriptive statistics in this work. Section 2 discusses the methodological issues in the panel data framework. Section 3 presents the empirical results and relevant discussions. And main concludes would be delivered at the end of the whole paper.

\section{EMPIRICAL MODELS AND VARIABLE STATIONARITY TEST}

\subsection{Empirical Models}

We first briefly show our empirical models, discuss our data sources, variable definitions, and give some summary statistics. We then give the empirical results and also report. As well, we briefly discuss some of the measured effects of the control variables and report additional robustness checks.

Following the standard literature and improving upon the theoretical postulate of Dimitris and Efthymios(2004), and take the hysteresis effect of real finance policy into account, we specify economic growth relationship as:

$$
\ln R J G D P=\alpha_{i}+\beta_{1 i} F I R_{i t-1}+\beta_{2 i} F I E_{i t-1}+\beta_{3 i} C T R_{i t-1}
$$

On the consideration of government participation, we generate a new empirical model including GOV (government participation) as follow:

$$
\begin{aligned}
& \ln R J G D P=\alpha_{i}+\beta_{1 i} F I R 1_{i t-1}+\beta_{2 i} F I R 2_{i t-1}+\beta_{3 i} F I R 3_{i t-1}+\beta_{4 i} F I E_{i t-1}+ \\
& \beta_{5 i} F I S_{i t-1}+\beta_{6 i} G O V_{i t-1}+\beta_{7 i} C T R_{i t-1}
\end{aligned}
$$

In the equation (1), (2) above, the dependent variable is InRJGDP indicates the economic growth, and $R J G D P=G D P / P o p u l a t i o n$ of region; FIR indicates finance amount, and FIR1 is the amount of loan, FIR2 is the share offerings, FIR3 is income of insurance premium. FIE is the indicator of efficiency of financial system, which is loan balance/ deposits. FIS means finance structure, and $F I S=$ stock financing/total financing. $G O V$ is a factor that represents government participation, $G O V=$ budgetary outlays/GDP. Finally, we choose the fixed assets investment (CTR) as the control variable.

2.2 Variable Stationary Test

This paper divided 31 provinces into 8 economic regions as 11th Five-Year development plan of China. All data is from Statistical yearbook of China issued by China National Bureau of Statistics.

2.2.1 Unit Root Test

The Table 1 report the outcome of unit toot test of 8 economic regions: 
Table 1 Unit Root Test on Main Variables

\begin{tabular}{cccc}
\hline economic regions & Mode & Statitics & P-Value \\
\hline North-East & Levin,Lin\&Chu t & -1.80578 & $0.0355^{* *}$ \\
economic region & PP-Fisher Chi-square & 51.8113 & $0.0148^{* *}$ \\
North economic region & Levin,Lin\&Chu t & -5.13118 & $0.0000^{* * *}$ \\
East & PP-Fisher Chi-square & 101.567 & $0.0019^{* * *}$ \\
economic region & Levin,Lin\&Chu t & -5.88957 & $0.0000^{* * *}$ \\
South & ADF-Fisher Chi-square & 86.0391 & $0.0006^{* * *}$ \\
economic region & Levin,Lin\&Chu t & -2.58197 & $0.0049^{* * *}$ \\
Middle of The & PP-Fisher Chi-square & 109.783 & $0.0000^{* * *}$ \\
Yellow River & Levin,Lin\&Chu t & -3.46078 & $0.0003^{* * *}$ \\
economic region & PP-Fisher Chi-square & 92.8334 & $0.0107^{* *}$ \\
Middle of The & Levin,Lin\&Chu t & -2.82895 & $0.0023^{* * *}$ \\
Yangtze River & PP-Fisher Chi-square & 66.4068 & $0.0403^{* *}$ \\
economic region & Levin,Lin\&Chu t & -5.64323 & $0.0000^{* * *}$ \\
South-West & PP-Fisher Chi-square & 145.967 & $0.0000^{* * *}$ \\
economic region & Levin,Lin\&Chu t & -0.53045 & $0.0979^{*}$ \\
North-West & PP-Fisher Chi-square & 71.4497 & $0.0001^{* * *}$ \\
economic region & accept the & & \\
\hline
\end{tabular}

Table 1 shows we cannot accept the null hypothesis of the existence of unit root at $10 \%$ significance level, so the original data is stable.

\subsubsection{Granger causality test}

The co-integration test indicates that there exists a long-term and stable relationship between economic growth and financial development. In order to determine their relationship, the Granger causality test is carried out, and the test results is shown in Table 2.

Table 2 Granger causality test on Main Variables

\begin{tabular}{|c|c|c|c|}
\hline economic regions & Original hypothesis & $\begin{array}{c}\text { Statistic } \\
\mathrm{S}\end{array}$ & P-Value \\
\hline \multirow{4}{*}{ North-East economic region } & FIE does not Granger Cause LNRJGDP & 9.5665 & 0.0114 \\
\hline & GOV does not Granger Cause LNRJGDP & 4.84286 & 0.0524 \\
\hline & CTR does not Granger Cause LNRJGDP & 8.72789 & 0.0144 \\
\hline & FIR3 does not Granger Cause LNRJGDP & 5.42474 & 0.0421 \\
\hline \multirow{2}{*}{ North economic region } & FIR3 does not Granger Cause LNRJGDP & 11.0158 & 0.0078 \\
\hline & CTR does not Granger Cause LNRJGDP & 13.6435 & 0.0042 \\
\hline \multirow[t]{2}{*}{ East economic region } & FIR1 does not Granger Cause LNRJGDP & 6.06367 & 0.0335 \\
\hline & FIR3 does not Granger Cause LNRJGDP & 9.21352 & 0.0126 \\
\hline \multirow[t]{2}{*}{ South economic region } & FIR3 does not Granger Cause LNRJGDP & 3.70160 & 0.0833 \\
\hline & FIE does not Granger Cause LNRJGDP & 5.55999 & 0.0401 \\
\hline \multirow{3}{*}{$\begin{array}{l}\text { Middle of The Yellow River } \\
\text { economic region }\end{array}$} & GOV does not Granger Cause LNRJGDP & 8.63248 & 0.0148 \\
\hline & CTR does not Granger Cause LNRJGDP & 24.0388 & 0.0006 \\
\hline & FIR2 does not Granger Cause LNRJGDP & 4.37897 & 0.0629 \\
\hline \multirow{3}{*}{$\begin{array}{l}\text { Middle of The Yangtze River } \\
\text { economic region }\end{array}$} & FIE does not Granger Cause LNRJGDP & 3.32283 & 0.0983 \\
\hline & CTR does not Granger Cause LNRJGDP & 6.66696 & 0.0273 \\
\hline & FIR3 does not Granger Cause LNRJGDP & 10.4517 & 0.0090 \\
\hline \multirow{2}{*}{ South-West economic region } & CTR does not Granger Cause LNRJGDP & 10.2606 & 0.0094 \\
\hline & FIR3 does not Granger Cause LNRJGDP & 5.66661 & 0.0386 \\
\hline \multirow{2}{*}{ North-West economic region } & FIR2 does not Granger Cause LNRJGDP & 3.89485 & 0.0767 \\
\hline & FIS does not Granger Cause LNRJGDP & 5.93747 & 0.0350 \\
\hline
\end{tabular}


The results of Granger causality test shows that we cannot accept the original hypothesis about the relation of main independent variables and InRJGDP. We will do empirical regression and analysis on the base of panel data above.

\section{EMPIRICAL STUDY ON THE EFFECT OF GOVERNMENT PATICIPATION}

\subsection{Hausman test}

The purpose of hausman test is terrify the random effect model or fixed effect model used in regression analysis.

3.2 The Regression result and Analysis Based on panel-data

3.2.1 We have choose corresponding model to analysis according to the results of hausman test. The test outcome is reported in Table 3 with regression results.

Table 3 Hausman test and Regression result

\begin{tabular}{ccccccccc}
\hline regions & model & FIR1 & FIR2 & FIR3 & FIS & FIE & GOV & CTR \\
\hline North- & fe & -0.51 & -15.65 & -12.02 & 9.47 & -0.09 & $12.08^{* * *}$ & $0.98^{* * *}$ \\
east & re & $0.94^{* * *}$ & -22.5 & $-31.65^{* * *}$ & 14.92 & $-2.99^{* * *}$ & 2.64 & $1.51^{* * *}$ \\
\multirow{2}{*}{ North } & fe & 0.39 & 2.04 & 3.67 & -2.88 & -0.55 & $12.69^{* * *}$ & $1.91^{* * *}$ \\
& re & 0.33 & $-11.78^{* * *}$ & 0.41 & 30.11 & -0.35 & $8.6^{* * *}$ & $2.33^{* * *}$ \\
\multirow{2}{*}{ East } & fe & $0.66^{* * *}$ & $21.14^{* * *}$ & $-29.04^{* * *}$ & $-29.08^{* * *}$ & -1.7 & $16.44^{* * *}$ & $2.61^{* * *}$ \\
& re & 0.26 & $22.68^{* * *}$ & -37.96 & $-36.85^{* * *}$ & -1.03 & $14.95^{* * *}$ & $3.35^{* * *}$ \\
South & fe & -0.65 & -51.3 & 56.24 & 50.71 & -1.48 & $-7.26^{* * *}$ & $6.76^{* * *}$ \\
& re & 0.01 & 0.01 & 0 & 0.01 & 0 & $00^{* * *}$ & 0 \\
Yellow & fe & -0.3 & -12.91 & -2.21 & 12.18 & -0.53 & 1.49 & $3.17^{* * *}$ \\
river & re & $-1.34^{* * *}$ & 11.65 & 1.59 & -9.39 & -0.55 & $3.04^{* * *}$ & $2.58^{* * *}$ \\
Yangtz & fe & $-1.32^{* * *}$ & -1.37 & 3.58 & -2.24 & $0 * * *$ & $8.34^{* * *}$ & $1.17^{* * *}$ \\
e River & re & $-1.42^{* * *}$ & -4.57 & 5.88 & 1.86 & $0 * * *$ & $8.88^{* * *}$ & $1.02^{* * *}$ \\
South- & fe & $-1.05^{* * *}$ & 7.17 & -7 & -5.81 & -0.08 & $4.37^{* * *}$ & $3.2^{* * *}$ \\
west & re & -0.23 & 3.44 & -5.28 & -0.76 & 0 & 2.24 & $3.4^{* * *}$ \\
North- & fe & -1.35 & 13.22 & 11.63 & -22.97 & -0.63 & -1.33 & $3.11^{* * *}$ \\
west & re & $-2.91^{* * *}$ & $27.49^{* * *}$ & $27.37^{* * *}$ & $-35.87 * * *$ & 0.79 & -3.41 & $4.44^{* * *}$ \\
\hline
\end{tabular}

\subsubsection{Analysis about regression results}

Based on panel data of 8 regions of China during 2000-2013, this paper empirically test the relation between financial development and economic growth on the consideration of government participation. The regression results shows that:

(1) Efficiency of financial system (FIE) has a negative and significant effect on InRJGDP. 8 regions have encountered the same situation. It means the effect of finance transition efficiency on economic growth were not totally released in past decades;

(2) The finance amount (FIR) had different effect on economic growth in 8 regions. Such as the increase of FIR1 had a positive effect on InRJGDP in North-east economic region and South economic region, but negative in Middle of The Yellow River economic region, Middle of The Yangtze River economic region and North-West economic region.

(3) The government participation has a significant and positive role in most regions but negative influence in North-west and South economic region.

\section{CONCLUSION}

The results presented in this paper provide empirical support for the idea that the government have played an important role in finance development and economic growth in each region. But the effect of government participation has diverse effect on finance scale or finance transition efficiency in different regions. We also found that efficiency of financial system (FIE) has a negative and significant effect on economic growth.

Moreover, the econometric results on the panel of region-years observations strongly supports a positive, significant and sizeable effect of fixed assets investment (CTR). Which means the amazing progress in GDP resulted mainly from fixed assets investment. And we can get reasonable 
interpretation the local governments were wild about the projects of infrastructure construction, such as high-way and railway.

Based on these empirical studies, it is believed that the government has played a magnificent role in the relation of finance development and economic growth. Government need choose appropriate approach to promote finance development according to different circumstance and conditions. And local government need to transfer their focus of participation process, not only on finance scale, but also on efficiency of financial system. Only in this way, they will get economic growth in long run. Obviously more works about the role of government need to be done.

\section{Acknowledgements}

National Social Science Fund of China(14XJL004), Humanities and Social Science Project of Chongqing Municipal Education Commission(14SKG009).

\section{REFERENCES}

[1]. Asli Demirguc-Kunt, Erik Feyen, and Ross Levine. Optimal Financial Structures and Development: The evolving importance of banks and markets. The world research paper. June 3, 2011.

[2]. Arturo Galindo, Fabio Schiantarelli, Andrew Weiss. Does financial liberalization improve the allocation of investment? Micro-evidence from developing countries. Journal of Development Economics, 83 (2007) 562 - 587.

[3]. Chen HAO. Development of financial intermediation and economic growth: The Chinese experience. China Economic Review 17 (2006) 347 - 362.

[4]. Dexu H, Yao Zhanqi. On the Industrial Relationship of China's Financial Service Industry[J]. Journal of Financial Research, 2006, 51(5):1-15.

[5]. Jianbo XU, Haiyong XIA. Financial Development and Economic Growth: Is It Government Intervention the Matter. Journal of economic issues, 2014,07:41-47.

[6]. Joseph E. Stiglitz, Jaime Jaramillo-Vallejo, and Yung Chal Park. The role of the state in financial markets. World Bank Research Observer, Annual Conference on Development Economics Supplement (1993):19-61.

[7]. Qi LIANG, Jian-Zhou TENG. Financial development and economic growth: Evidence from China. China Economic Review 17 (2006) 395-411. 